\title{
How to turn an ocean liner: a proposal for voluntary degrowth by redesigning money for sustainability, justice, and resilience
}

\author{
Alf Hornborg ${ }^{1}$ \\ Lund University, Sweden
}

\begin{abstract}
This article argues that many destructive aspects of the contemporary global economy are consequences of the use of general-purpose money to organize social and human-environmental relations, and that the political ideals of sustainability, justice, and resilience will only be feasible if money itself is redesigned. The argument is based on the conviction that human artifacts such as money play a crucial role in organizing society, and that closer attention should be paid to the design and logic of key artifacts, rather than devoting disproportionate intellectual energy to theorizing their complex systemic repercussions. What is generally referred to as "capitalism" is the aggregate logic of human decisions about the management of money. Visions of a post-capitalist society using money the way it is used now is thus a contradiction in terms. The article sketches a possible redesign of money based on the idea that each country establishes a complementary currency for local use only, which is distributed to all its residents as a basic income. The distinction between two separate spheres of exchange would insulate local sustainability and resilience from the deleterious effects of globalization and financial speculation. To indicate that the suggestion is not as unrealistic as it may seem at first sight, the article briefly and provisionally responds to some of the many questions raised by the proposal.
\end{abstract}

Keywords: Resilience, money, degrowth, capitalism

\section{Résumé}

Cet article soutient que de nombreux aspects destructifs de l'économie mondiale contemporaine sont des conséquences de l'utilisation d'argent à usage général pour organiser des relations sociales et humainesenvironnementales, et que les idéaux de politiques de durabilité, de justice et de résilience ne seront possibles que si cet argent est reconçu. L'argument repose sur la conviction que les artefacts humains tels que l'argent jouent un rôle fondamental dans l'organisation de la société, et qu'une méditation plus attentive devrait être accordée à la conception et à la logique de ces artefacts clés, plutôt que de consacrer une énergie intellectuelle disproportionnée à théoriser leurs répercussions systémiquement complexes. Ce que l'on appelle généralement le «capitalisme» est la logique prépondérante des décisions humaines sur la gestion d'argent. Les visions d'une société post-capitaliste, utilisant l'argent de la façon dont il est actuellement utilisé, est en principe une contradiction. L'article esquisse une éventuelle conception d'argent basé sur l'idée que chaque pays établisse une monnaie complémentaire pour usage local qui est distribuée à tous ses résidents comme un revenu de base. La distinction entre les deux domaines différents d'échange isolerait la durabilité locale et la résilience des effets nuisibles de la mondialisation et de la spéculation financière. Pour montrer que la suggestion n'est pas tout à fait irréaliste comme elle initialement pourrait paraître, l'article répond brièvement et provisoirement à certaines des questions soulevées par cette proposition.

Mots-clés: Résilience, l'argent, décroissance, capitalisme

\section{Resumen}

Este artículo arguye que muchos de los aspectos destructivos de la economía global contemporánea son consecuencias del uso del dinero de propósito general para organizar las relaciones sociales y humanoambientales. Propone que los ideales políticos de sostenibilidad, justicia y resiliencia sólo serán factibles si el dinero mismo es rediseñado. El argumento se basa en la convicción de que los artefactos humanos

\footnotetext{
${ }^{1}$ Alf Hornborg, Professor, Human Ecology Division, Lund University, Sweden. alf.hornborg "at" hek.lu.se. This article overlaps with a European Policy Brief posted on the website of the project Financialisation, economy, society and sustainable development (FESSUD), the support of which I hereby acknowledge (Hornborg 2015). This is the twelth article in Lisa L. Gezon and Susan Paulson (eds.) 2017. "Degrowth, culture and power", Special Section of the Journal of Political Ecology, 24: 425-666.
} 
como el dinero cumplen un rol crucial en la organización de la sociedad y que se debe prestar más atención al diseño y la lógica de los artefactos clave, en lugar de dedicar una energía intelectual desproporcionada a teorizar sus complejas repercusiones sistémicas. Lo que generalmente se conoce como "capitalismo" es la lógica agregada de las decisiones humanas sobre la gestión del dinero. Las visiones de una sociedad postcapitalista que utilizan el dinero de la manera en que se usa ahora es, pues, una contradicción en términos. El artículo esboza un posible rediseño de dinero basado en la idea de que cada país establezca una moneda complementaria para uso local, la cual se distribuya a todos sus residentes como un ingreso básico. La distinción entre estas dos esferas de intercambio aislaría las dinámicas hacía la resiliencia y la sostenibilidad local de los efectos deletéreos de la globalización y la especulación financiera. Para indicar que la sugerencia no es tan irreal como parece a primera vista, el artículo responde brevemente y provisionalmente a algunas de las muchas preguntas generadas por la propuesta.

Palabras clave: Resiliencia, dinero, decrecimiento, capitalismo

\section{Background}

Judging from public discourse, the early 1970s in Europe and North America were a time of disillusionment. The optimism of the post-war decades had been replaced by a gloomy understanding of global capitalism and a dystopian anticipation of crisis. The economic expansion of the 1950s and 1960s had fostered general optimism even as the environmental movement began questioning the foundations of industrial society. The message of Silent spring (Carson 1962) had been a wakeup call, ominous but still possible to handle by a credible, modernist political establishment. The Vietnam War raised critical questions about the role of economically developed nations in an increasingly unequal world order, but even these doubts had seemed surmountable by a new and emancipated generation championing civil rights and announcing the arrival of the Age of Aquarius.

A few years later, however, the optimism of the various social movements so diagnostic of modernity decisively gave way to post-modern hesitations about the economy, the future, and even our construction of reality. In 1971, excessive military expenditures in Vietnam forced President Nixon to abandon the Bretton Woods gold standard, leaving the dollar - and so much else - without a solid referent. The same year saw not only the birth of NASDAQ and electronic money but the publication of several foundational critiques of the industrial economy, which up to then had been growing incessantly for a quarter of a century, including Nicholas Georgescu-Roegen's The entropy law and the economic process (1971) and Howard Odum's Environment, power and society (1971). The following year saw the publication of the Club of Rome report The limits to growth (Meadows et al. 1972), Arghiri Emmanuel's (1972) classic analysis of the imperialism of international trade, and the United Nations' first Conference on Environment and Development, in Stockholm, followed in 1973 by the traumatic global oil crisis and the publication of E.F. Schumacher's Small is beautiful: a study of economics as if people mattered (1973). In the years 1971-1973, in other words, a very widespread reappraisal of economic growth, technological development, and the reliance on fossil fuel energy shook Euro-American society. ${ }^{2}$

While economic growth and the concomitant expansion of societal metabolism today continue to be promoted as the supreme purpose of human societies, we are still struggling to make sense of that traumatic loss of modernist self-confidence over forty years ago. Current deliberations on sustainability suggest a frustrating impasse. In this article, rather than report ethnographically on a specific local experience of this impasse, I shall try to account for how it is rooted in the very fabric of our modern categories. I will argue that the fundamental categories of modern thought, aligned as they are with the features we have attributed to the artifacts which organize our economy, are a common denominator of a myriad social and ecological problems experienced by people worldwide.

Although soon reduced to a heterodox and marginalized position, the critique of growth has continued to challenge mainstream dogmas of economics and policy for over four decades. Countless debates have raged on what exactly is the problem of sustainability, whether the design of taxes and subsidies, the choice of energy sources, the internal contradictions of capitalism, or even the biological essence of the human species. Considering the centrality of the focus on the economy, it is remarkable

\footnotetext{
${ }^{2}$ In his posthumously published book Good work Schumacher specifies "the date when a hole appeared in the skin of the balloon" as October 6, 1973 (1979: ch.1). This was the date when it became evident to the world that economic growth was contingent on oil prices.
} 
how little attention has been paid to the phenomenon of money. Mainstream economists certainly do not question money, but neither do most Marxists or ecological economists. Even Georgescu-Roegen (1971), who is recognized as the origin of both ecological economics and the proposal for degrowth, wrote a 457-page book on the contradiction between economics and thermodynamics without once asking if the cultural convention we know as money might in fact be the elephant in the room.

The use of money in a given context reflects the ideas people in that context have about the interchangeability or commensurability of various goods and services. Different kinds of money have been used in different social and cultural contexts for thousands of years, but the extent to which goods and services became interchangeable on the market in nineteenth-century Europe was unprecedented (Polanyi 1944). To say that land and labor were extensively commoditized in this period is tantamount to saying that they became exchangeable for money. In pre-modern societies, monetized exchange was largely limited to long-distance trade in preciosities, while most basic needs were provided through socially embedded relations of reciprocity and redistribution. Then, in nineteenth-century Europe, amid radical institutional changes, money became a medium to obtain all kinds of goods and services, including food and other everyday needs. This is what economic anthropologists mean by "generalpurpose money," as distinct from different kinds of non-modern "special-purpose money," which reflect more limited principles of commensurability within distinct spheres of exchange (Bohannan 1955).

In this article I argue that there is an inherent logic in general-purpose money that promotes an ambiguous form of "efficiency" implying maximum exploitation of global differences in wage levels, land prices, and environmental legislation, which means encouraging long-distance transports, economic and environmental inequalities, and a pervasive indifference with regards to the distant social and ecological consequences of consumption (what is sometimes referred to as "consumer blindness"). Although we tend to deplore such negative aspects of globalization, we may have to concede that they are implications of an economy organized in terms of general-purpose money. Given the basic imperative of minimizing costs and maximizing income, defined by the logic of such money, mainstream economists may be right in that there is no alternative - within their field of vision. The aim of this article, however, is to sketch the operation of a different kind of currency system, which would promote a non-capitalist definition of efficiency, encouraging local resource management and frugality, social and ecological resilience, food security, and community. Whereas general-purpose money tends to generate economic globalization, the proposal for a complementary, special-purpose currency presented here is offered as a way of relocalizing the bulk of economic interaction.

If, in the early 1970s, many people realized that there were several problems with a societal focus on economic growth and productivism, few recognized that the imperative to pursue growth is inherent in the phenomenon of general-purpose money itself. The imperative of minimizing costs and maximizing income, and the myriad practices, regulations, and institutions through which such strategies are organized, reflects the logical repercussions of the very idea of a universal solvent making all needs commensurable. Few people tend to reflect over general-purpose money as a cultural peculiarity to which there are alternatives. Economic anthropologists, however, will recall Paul Bohannan's (1955) account of the "multicentric" economy of the Tiv of Nigeria, which exemplifies the widespread occurrence among premodern peoples of a hierarchy of economic values, in which different categories of goods and services are not readily exchanged for other categories (among the Tiv, for instance, there was hesitation about exchanging labor or prestige goods for food). Regardless of the particular idiosyncrasies of such distinctions, the principle that they express - the assertion of limits to commensurability - is a radical challenge to the market ideology that has since transformed the economy of the Tiv and so many other indigenous peoples throughout the world. Although the very idea is anathema to mainstream economics, the argument in this article is that it may actually be a key to alleviating global problems of declining sustainability.

I will go even further by suggesting that it is precisely in their inability to think beyond contemporary systems of money that heterodox approaches such as Marxism and ecological economics fail to offer feasible alternatives to business-as-usual. The exploitative dynamics of "capitalism" and the "underpayment" of environmental resources are expressions of the logic of general-purpose money, which assumes and encourages the exchange of industrial products for increasing amounts of the resources spent in producing them (Hornborg 2016). The metric offered for measuring both "surplus labor value" (Emmanuel 1972) and the "value of ecosystem services" (Costanza et al. 1997) is always money. In both cases, the envisaged inadequacy of compensation is a logical consequence of the 
systematic struggle of market actors to keep costs lower than incomes. When such "efficiency" is pursued not at the local level, where Adam Smith identified its benefits, but in a globalized economy where fossil fuels have minimized transport costs, the scope for power differences, polarization and exploitation - and thus the collateral damage of "efficiency" - is vastly greater. "Efficiency," in fact, is inverted into its opposite. As long as we subscribe to the assumption of general-purpose money as the medium of exchange organizing human societies, exploitation and underpayment are inevitable implications of production processes. Although he did not draw this conclusion himself, it is solidly founded on the interdisciplinary insights of none other than Nicholas Georgescu-Roegen (1971), who famously showed that the production of exchange value simultaneously increases biophysical entropy.

The period after the 1971 abandonment of a gold standard has revealed the long-term trajectory of general-purpose money. Since the introduction in Europe of paper money in the fourteenth century, and the first major financial crisis in Florence in 1343 (Weatherford 1997: 78), the risks of detaching money from finite, material parameters have repeatedly become evident. In the 628 years between 1343 and 1971, the aggregate consequences of states, banks, and market actors maximizing their monetary assets have included long-term tendencies toward increasing economic inequalities and environmental degradation, punctuated by points of extensive monetary devaluation illustrating the fundamental vulnerability of states, financial institutes, and people at large. Although a great number of policy suggestions have been presented to attempt to remedy such recurrent tendencies and events, mainstream proposals do not critically scrutinize the inherent features of money itself. Nor, as we have observed, do most proposals from non-mainstream camps such as Marxism and ecological economics. This article considers what such a critical scrutiny would entail, and some possible conclusions. It does not belittle the technological and societal accomplishments in Europe since the fourteenth century, most of which have been connected to entrepreneurship in the context of a capitalist economy, but suggests that current concerns with climate change and financial crises offer a historical moment for reflection on how the operation of the global economy might be reorganized in the interests of global sustainability, justice, and financial resilience.

In the wake of the financial crisis of 2008, it has become increasingly acceptable to advocate more elaborate societal regulation of the economy. To counteract the runaway logic of unregulated private finance, there have been calls for innovation in public finance. A fundamental challenge for actors representing public interests is how to establish regulatory frameworks for alleviating risk and vulnerability without seriously discouraging private actors from innovative contributions that are of benefit for society at large. In order to progress in meeting this challenge, we need to emphasize some analytical distinctions which tend to be ignored in mainstream discourse, such as between market principles and capitalism, everyday local life versus global finance, and long-term sustainability and survival versus short-term gain. The societal objective must be to strike a balance between such distinct interests and concerns, which in my opinion means establishing ways of insulating them from each other, rather than allowing one to be absorbed by the other. We thus need to take seriously the recent surge of voices advocating degrowth, relocalization, post-capitalism, and the imperative of collectively changing the rules of the game.

A central question for those of us concerned with designing an economics for sustainability is whether the main concern of economic policy must be economic growth and maximum employment, or if it might prioritize environmental and social resilience, justice, and long-term survival, even if this would mean less-than-maximum encouragement of growth and employment. ${ }^{3}$ How this question is answered hinges on our framing assumptions, for example about the nature of money, efficiency, and exchange. As recent global negotiations on climate change have focused on issues no less drastic than drafting policies for saving the biosphere from human destruction, we need to ask ourselves if there really are limits to how imaginative we can be in proposing policy recommendations for a sustainable economy.

The burgeoning discourse on degrowth has so far been modest and ambivalent about radically transforming the central institutions of modern economic life. There have been sporadic references to the possible benefits of basic income (Alexander 2015; Gerber 2015; Kallis 2011) and community currencies (Dittmer 2013, 2015; Douthwaite 2012), but no systematic attempt to outline how such reforms could be

\footnotetext{
${ }^{3}$ Note that I here use "employment" in the conventional sense of formally salaried jobs. As my proposal will illustrate, there are alternative ways of mobilizing people to conduct useful and meaningful work.
} 
harnessed to the objectives of degrowth. The prospects of alternative currency systems have been favorably discussed by a limited number of writers explicitly advocating degrowth, among them Richard Douthwaite (2012). In the context of New Zealand, Emma McGuirk (2017) explores the transformative potential of everyday participation in Timebanks, institutions in which online currency is used to track labor exchanges among members, with one hour of any kind of work earning one time credit. Although I share Dittmer's (2013, 2015) and Blanc's (2012) misgivings about actual achievements of experiments with Local Exchange Trading Systems (LETS) and other forms of community currencies, I believe there is much to learn from these experiences that could help the degrowth movement envisage a concrete strategy for reaching its important objectives. Social experiments ranging from those of the utopian socialist Robert Owen in the early nineteenth century to the barter networks of Argentina in the beginning of the twenty-first have all been founded on the insight that general-purpose money functioning today is destructive of both social and human-environmental relations (North 2007). In fact, I cannot see any better strategy for economic relocalization - a frequently expressed goal among degrowth theorists - than to encode spatial distinctions into the currency system.

To be able to imagine and build an economy that does not continue to generate increasing inequalities, as well as greenhouse gas emissions, biodiversity loss, and other processes threatening to exceed planetary boundaries, we need to consider radically different ways of organizing human societies. This requires us to bracket conventional convictions about the requisites of a well-functioning economy, and to envisage feasible organizational changes that may modify human behavior patterns so as to increase sustainability and justice. In response to Susan Paulson's call to look at change in new ways (2017), articles in this Special Section ask how systems of culture and power produce and reproduce knowledge, socialized humans, their socionatural worlds, and all kinds of values. Here I envision changes in the regimes and institutions around money and monetary value. We need nothing less than a vision of a more sustainable and egalitarian future human society, and a feasible road map for getting there without abandoning our values regarding democracy, justice, and individual liberty. If it is indeed easier to imagine the end of the world than the end of capitalism, it is high time to discover the elephant in the room.

\section{Relocalization: how to do it (a proposal and 25 FAQs)}

Given these challenges, I ask how it would be possible to organize an economy that in at least three fundamental ways generates tendencies in directions diametrically opposite to those we observe in the world at present. Initial questions would be: how do we encourage human behavior patterns that increase rather than reduce sustainability, that reduce rather than increase vulnerability, and that diminish rather than increase inequalities? To obtain the first of these goals, the objective must be to reduce transport, emissions, resource use, and waste. To promote the second goal, the ideal must be to enhance food security, diversity, community, and resilience. To reach the third goal, finally, the aim must be to mitigate economic accumulation, polarization, and marginalization.

To encourage such modifications of human behavior without resorting to totalitarian politics and severe austerity measures, I offer the following general recommendation for a policy for sustainability and justice: Each country establishes a complementary currency for local use only, which is distributed to all its residents as a basic income. This outline of a policy proposal raises a long list of questions to which only preliminary answers can be provided here. The specific ways in which these questions can be answered represent options for calibrating the proposal with different kinds of constraints, whether particular to different areas or of a more universal nature. The following attempt to provide preliminary responses to some of these questions should thus be understood as preliminary and subject to meticulous negotiation, monitoring, and modification:

1. What is a complementary currency? It is a form of money that can be used alongside regular currency, without in any way legally restricting the use of regular money.

2. What is the fundamental goal of this proposal? The two most fundamental goals motivating this proposal are to insulate local human subsistence and livelihood from the vicissitudes of national and international economic cycles and financial speculation, and to provide tangible and attractive incentives for people to live and consume more sustainably. It also seeks to provide authorities with a means to employ social security expenditures to channel consumption in sustainable directions and encourage economic diversity and community resilience at the local level. 
3. Why should the state administrate the reform? The nation is currently the most encompassing political entity capable of administrating an economic reform of this nature. Ideally it is also subservient to the democratic decisions of its population. The current proposal is envisaged as an option for European nations, but would seem equally advantageous for countries anywhere. If successfully implemented within a particular nation or set of nations, the system can be expected to be emulated by others. Whereas earlier experiments with alternative currencies have generally been local, bottom-up initiatives, a state-supported program offers advantages for long-term success. Rather than an informal, marginal movement connected to particular identities and transient social networks, persisting only as long as the enthusiasm of its founders, the complementary currency advocated here is formalized, efficacious, and lastingly fundamental to everyone's economy.

4. How is local use defined and monitored? The complementary currency (CC) can only be used to purchase goods and services that are produced within a given geographical radius of the point of purchase. This radius can be defined in terms of kilometers of transport, and it can vary between different nations and regions depending on circumstances. A fairly simple way of distinguishing local from non-local commodities would be to label them according to transport distance, much as is currently done regarding, for instance, organic production methods or "fair trade." Such transport certification would of course imply different labelling in different locales.

5. How is the complementary currency distributed? A practical way of organizing distribution would be to provide each citizen with a plastic card which is electronically charged each month with the sum of CC allotted to him or her.

6. Who are included in the category of citizens? A monthly CC is provided to all inhabitants of a nation who have received official residence permits.

7. What does basic income mean? Basic income is distributed without any requirements or duties to be fulfilled by the recipients. The sum of CC paid to an individual each month can be determined in relation to the currency's purchasing power and to the individual's age. The guiding principle should be that the sum provided to each adult should be sufficient to enable basic existence, and that the sum provided for each child should correspond to the additional household expenses it represents.

8. Why would people want to use their CC rather than regular money? As the sum of CC provided each month would correspond to purchases representing a claim on his or her regular budget, the basic income would liberate a part of each person's regular income and thus amount to substantial purchasing power, albeit restricted only to local purchases. The basic income in CC would reduce a person's dependence on wage labor and the risks currently associated with unemployment. It would encourage social cooperation and a vitalization of community.

9. Why would businesses want to accept payment in CC? Business entrepreneurs can be expected to respond rapidly to the radically expanded demand for local products and services, which would provide opportunities for a diverse range of local niche markets. Whether they receive all or only a part of their income in the form of CC, they can choose to use some of it to purchase tax-free local labor or other inputs, and to request to have some of it converted by the authorities to regular currency (see next point).

10. How is conversion of CC into regular currency organized? Entrepreneurs would be granted the right to convert some of their CC into regular currency at exchange rates set by the authorities. The exchange rate between the two currencies can be calibrated so as to compensate the authorities for loss of tax revenue and to balance the in- and outflows of CC to the state. The rate would thus amount to a tool for determining the extent to which the CC is recirculated in the local economy, or returned to the state. This is important in order to avoid inflation in the CC sector.

11. Would there be interest on sums of CC owned or loaned? There would be no interest accruing on a sum of CC, whether a surplus accumulating in an account or a loan extended.

12. How would saving and loaning of CC be organized? The formal granting of credit in CC would be managed by state authorities and follow the principle of full reserve banking, so that quantities of CC loaned would never exceed the quantities saved by the population as a whole.

13. Would the circulation of CC be subjected to taxation? No. 
14. Why would authorities want to encourage tax-free local economies? Given the beneficial social and ecological consequences of this reform, it is assumed that nation states will represent the general interests of their electorates and thus promote it. Particularly in a situation with rising fiscal deficits, unemployment, health care, and social security expenditures, the proposed reform would alleviate financial pressure on governments. It would also reduce the rising costs of transport infrastructure, environmental protection, carbon offsetting, and climate change adaptation. In short, the rising costs and diminishing returns on current strategies for economic growth can be expected to encourage politicians to consider proposals such as this, as a means of avoiding escalating debt or even bankruptcy.

15. How would the state's expenditures in CC be financed? As suggested above, much of these expenditures would be balanced by the reduced costs for social security, health care, transport infrastructure, environmental protection, carbon offsetting, and climate change adaptation. As these savings may take time to materialize, however, states can choose to make a proportion of their social security payments (pensions, unemployment insurance, family allowance, etc.) in the form of CC. As between a third and half of some nations' annual budgets are committed to social security, this represents a significant option for financing the reform, requiring no corresponding tax levies.

16. What are the differences between this CC and the many experiments with local currencies? This proposal should not be confused with the notion, or with the practical operation, of local currencies, as it does not imply different currencies in different locales but one national, complementary currency for local use. Nor is it locally initiated and promoted in opposition to the regular currency, but centrally endorsed and administrated as an accepted complement to it. Most importantly, the alternative currency can only be used to purchase products and services originating from within a given geographical range, a restriction which is not implemented in experiments with Local Exchange Trading Systems (LETS). Finally, the CC is provided as a basic income to all residents of a nation, rather than only earned in proportion to the extent to which a person has made him- or herself useful in the local economy.

17. What would the ecological benefits be? The reform would radically reduce the demand for longdistance transport, the production of greenhouse gas emissions, consumption of energy and materials, and losses of foodstuffs through overproduction, storage, and transport. It would increase recycling of nutrients and packaging materials, which means decreasing leakage of nutrients and less garbage. It would reduce agricultural intensification, increase biodiversity, and decrease ecological degradation and vulnerability.

18. What would the societal benefits be? The reform would increase local cooperation, decrease social marginalization and addiction problems, provide more physical exercise, improve psychosocial and physical health, and increase food security and general community resilience. It would decrease the number of traffic accidents, provide fresher and healthier food with less preservatives, and improved contact between producers and consumers.

19. What would the long-term consequences be for the economy? The reform would no doubt generate radical transformations of the economy, as is precisely the intention. There would be a significant shift of dominance from transnational corporations founded on financial speculation and trade in industrially produced foodstuffs, fuels, and other internationally transported goods to locally diverse producers and services geared to sustainable livelihoods. This would be a democratic consequence of consumer power, rather than of legislation. Through a relatively simple transformation of the conditions for market rationality, governments can encourage new and more sustainable patterns of consumer behavior. In contrast to much of the drastic and often traumatic economic change of the past two centuries, these changes would be democratic and sustainable and would improve local and national resilience.

20. Why should society want to encourage people to refrain from formal employment? It is increasingly recognized that full or high employment cannot be a goal in itself, particularly if it implies escalating environmental degradation and energy and material throughput. Well-founded calls are thus currently made for degrowth, i.e. a reduction in the rate of production of goods and services that are conventionally quantified by economists as constitutive of GDP. Whether formal unemployment is the result of financial decline, technological development, or intentional policy for sustainability, no modern nation can be expected to leave its citizens economically 
unsupported. To subsist on basic income is undoubtedly more edifying than receiving unemployment insurance; the CC system encourages useful community cooperation and creative activities rather than destructive behavior that may damage a person's health.

21. Why should people receive an income without working? As observed above, modern nations will provide for their citizens whether they are formally employed or not. The incentive to find employment should ideally not be propelled only by economic imperatives, but more by the desire to maintain a given identity and to contribute creatively to society. Personal liberty would be enhanced by a reform which makes it possible for people to choose to spend (some of) their time on creative activities that are not remunerated on the formal market, and to accept the tradeoff implied by a somewhat lower economic standard. People can also be expected to devote a greater proportion of their time to community cooperation, earning additional CC, which means that they will contribute more to society - and experience less marginalization - than the currently unemployed.

22. Would savings in CC be inheritable? No.

23. How would transport distances of products and services be controlled? It is reasonable to expect the authorities to establish a special agency for monitoring and controlling transport distances. It seems unlikely that entrepreneurs would attempt to cheat the system by presenting distantly produced goods as locally produced, as we can expect income in regular currency generally to be preferable to income in CC. Such attempts would also entail transport costs which should make the cargo less competitive in relation to genuinely local produce, suggesting that the logic of local market mechanisms would by and large obviate the problem.

24. How would differences in local conditions (such as climate, soils, and urbanism) be dealt with? It is unavoidable that there would be significant variation between different locales in terms of the conditions for producing different kinds of goods. This means that relative local prices in CC for a given product can be expected to vary from place to place. This may in turn mean that consumption patterns will vary somewhat between locales, which is predictable and not necessarily a problem. Generally speaking, a localization of resource flows can be expected to result in a more diverse pattern of calibration to local resource endowments, as in premodern contexts. The proposed system allows for considerable flexibility in terms of the geographical definition of what is categorized as local, depending on such conditions. In a fertile agricultural region, the radius for local produce may be defined, for instance, as $20 \mathrm{~km}$, whereas in a less fertile or urban area, it may be $50 \mathrm{~km}$. People living in urban centers are faced with a particular challenge. The reform would encourage an increased production of foodstuffs within and in the vicinity of urban areas, which in the long run may also affect urban planning. People might also choose to move to the countryside, where the range of subsistence goods that can be purchased with CC will tend to be greater. In the long run, the reform can be expected to encourage a better fit between the distribution of resources (such as agricultural land) and demography. This is fully in line with the intention of reducing long-distance transports of necessities.

25. What would the consequences be if people converted resources from one currency sphere into products or services sold in another? It seems unfeasible to monitor and regulate the use of distant imports (such as machinery and fuels) in producing produce for local markets, but as production for local markets is remunerated in CC, this should constitute a disincentive to invest regular money in such production processes. Production for local consumption can thus be expected to rely mostly - and increasingly - on local labor and other resource inputs.

\section{Conclusions}

The ecological and societal destructiveness of what we call capitalism is inherent in the cultural meme of general-purpose money: the imperative of minimizing costs and maximizing income. Given such money, the most rational thing for market actors to do is to purchase the least expensive commodities. In a local community context, the aggregate logic of such behavior does seem to yield benefits for all concerned, as Adam Smith envisaged. In a globalized economy with low transport costs, however, market logic has tended to increase economic inequalities and environmental degradation. Everyday consumption patterns have tended to favor the commodities embodying the lowest paid labor, significant greenhouse gas emissions from transports, and the least concern for the natural environment. The use of general-purpose money at the global scale thus inexorably generates increasing inequalities, 
transportation, greenhouse gas emissions, climate change, and other forms of damage to the environment. As these processes are inherent consequences of general-purpose money, any attempt to curb such processes while continuing to comply with the rationality defined by general-purpose money will produce legislation raising the protests of economists and enterprise, such as protectionism and taxation aiming to inhibit economic activity. Given the conceptual constraints of general-purpose money and their specific definition of market "efficiency," mainstream economists perhaps cannot be faulted for endorsing economic strategies that increase inequalities and threaten to make the planet uninhabitable for human beings. ${ }^{4}$

Degrowth requires a currency system with a different logic, providing market actors with a special-purpose money which incites them to purchase commodities embodying local labor, a minimum of transports and greenhouse gas emissions, and concern for the local environment. A voluntary transition to degrowth, if at all possible, would require a democratic transformation of the structural conditions for market rationality. Given the new, localizing rationality introduced by the option of using a complementary currency as outlined here, the notion of "consumer power" would finally approximate the benevolent aspirations of market doctrine professed since the eighteenth century, generating more equitable and sustainable practices as a logical consequence of how the currency system is designed.

\section{References}

Alexander, S. 2015. Prosperous descent: crisis as opportunity in an age of limits. Amazon Createspace.

Blanc, J. 2012. Thirty years of community and complementary currencies: a review of impacts, potential and challenges. International Journal of Community Currency Research 16: 1-4.

Bohannan, P. 1955. Some principles of exchange and investment among the Tiv. American Anthropologist 57: 60-70.

Carson, R. 1962. Silent spring. Boston: Houghton Mifflin.

Costanza, R., R. d'Arge, R. de Groot, S. Farber, M. Grasso, B. Hannon, K. Limburg, S. Naeem, R. O'Neill, J. Paruelo, R. Raskin, P. Sutton and M. van den Belt. 1997. The value of the world's ecosystem services and natural capital. Nature 387: 253-260.

Dittmer, K. 2013. Local currencies for purposive degrowth? A quality check of some proposals for changing money-as-usual. Journal of Cleaner Production 54: 3-13. Researchgate

Dittmer, K. 2015. Community currencies. In D'Alisa, G., F. Demaria and G. Kallis (eds.). 2015. Degrowth: a vocabulary for a new era. London: Routledge. Pp. 149-151.

Douthwaite, R. 2012. Degrowth and the supply of money in an energy-scarce world. Ecological Economics 84: 187-193.

Emmanuel, A. 1972. Unequal exchange: a study of the imperialism of trade. New York: Monthly Review Press.

Georgescu-Roegen, N. 1971. The entropy law and the economic process. Cambridge: Harvard University Press.

Gerber, J. 2015. An overview of local credit systems and their implications for post-growth. Sustainability Science 10: 413-423.

Hornborg, A. 2015. Redesigning money to curb globalization: can we domesticate the root of all evil? Working Paper 91. EU: FESSUD project (Financialisation, Economy, Society and Sustainable Development).

Hornborg, A. 2016. Global magic: technologies of appropriation from Ancient Rome to Wall Street. Houndmills: Palgrave Macmillan.

Kallis, G. 2011. In defence of degrowth. Ecological Economics 70: 873-880.

Meadows, D., D. Meadows, J. Randers and W. Behrens III. 1972. Limits to growth. New York: New American Library.

\footnotetext{
${ }^{4}$ As Ruggiero (2013) has shown brilliantly, successive schools of economic thought from John Locke to neoliberalism have justified and encouraged various forms of social injustice. While this ideological function of economics may provoke our moral indignation, we need to remind ourselves that it is not so much a consequence of corruption and conspiracy as of the inertia of the money artifact to which we have delegated the operation of society.
} 
North, P. 2007. Money and liberation: the micropolitics of alternative currency movements. Minneapolis: University of Minnesota Press.

McGuirk, E. 2017. Timebanking in New Zealand as a prefigurative strategy within the wider degrowth movement. Journal of Political Ecology 24: 595-609.

Odum, H. 1971. Environment, power, and society. New York: Wiley-Interscience.

Paulson, S. 2017. Degrowth: culture, power and change. Journal of Political Ecology 24: 425-448.

Polanyi, K. 1944. The great transformation: the political and economic origins of our time. Boston: Beacon.

Ruggiero, V. 2013. The crimes of the economy: a criminological analysis of economic thought. London: Routledge.

Samuel, A. 2015. Basic and maximum income. In D'Alisa G., F. Demaria and G. Kallis (eds.). 2015. Degrowth: a vocabulary for a new era. London: Routledge. Pp. 146-148.

Schumacher, E. 1973. Small is beautiful: a study of economics as if people mattered. New York: Harper \& Row.

Schumacher, E. 1979. Good work. London: Jonathan Cape.

Weatherford, J. 1997. The history of money: from sandstone to cyberspace. New York: Three Rivers Press. 